\title{
Thermomechanical Response of LNG Concrete Tank to Cryogenic Temperatures
}

\author{
L. Dahmani \\ Mouloud Mammeri University, Tizi-Ouzou, Algeria \\ lahlou_d@yahoo.fr
}

УДК 539.4

\section{Термомеханическое нагружение бетонного резервуара со сжиженным природным газом при криогенных температурах}

\section{Л. Дахмани}

Университет им. Мулуда Маммери, Тизи-Узу, Алжир

Исследуются железобетонные резервуары для хранения сжиженного природного газа, имеющие ряд преимуществ перед стальными (высокая криогенная прочность, сопротивление термошоку, усталости и потере устойчивости, огнеупорность и т.д.). Поскольку основным недостатком железобетонных резервуаров является низкая прочность при растяжении, для оченки уровня термических растягиваюших напряжений разработана численная модель, которая описывает их термомеханическое состояние при криогенных температурах с учетом температурных зависимостей теплофизических свойств бетона, в том числе теплопроводности и удельной теплоемкости.

Ключевые слова: термомеханический расчет, резервуар для хранения сжиженного газа, криогенная температура, бетон.

Introduction. This paper discusses the principal aspects of the numerical evaluation of thermal stress induced by LNG (liquefied natural gas) in the concrete tank.

Since low temperature applications imply thermal stresses, temperature distribution data of thermal analysis is required in the coupled field analysis finally to obtain and analyze thermal stresses. It is, therefore, proposed to solve a heat conduction problem using finite element method to obtain temperature distribution data of a concrete tank at cryogenic temperatures.

The basis for thermal analysis in ANSYS [1,2] is a heat balance equation obtained from the principle of conservation of energy. The finite element solution performed via ANSYS yields nodal temperatures, and then uses the nodal temperatures to obtain other thermal quantities. The elastic stresses, induced by mechanical constraints and thermal strains resulting from the previous analysis, have been calculated.

Finite Element Model. A solid concrete LNG tank model of $15 \mathrm{~m}$ radius and $30 \mathrm{~m}$ height shown in Fig. 1 is descretized with a 2D axisymetric finite element model [3] as shown in Fig. 2. Its mechanical properties are given in Table 1. 
$\mathrm{T}$ a b 1 e 1

\section{Mechanical Properties of Concrete}

\begin{tabular}{|c|c|c|c|c|c|c|}
\hline \multicolumn{2}{|c|}{ Physical parameters } & \multicolumn{5}{|c|}{ Values } \\
\hline \multicolumn{2}{|c|}{ Mass density } & \multicolumn{5}{|c|}{$\rho=2400 \mathrm{~kg} / \mathrm{m}^{3}$} \\
\hline \multicolumn{2}{|l|}{ Concrete compressive strength } & \multicolumn{5}{|c|}{$f_{c 28}=25 \mathrm{MPa}$} \\
\hline \multicolumn{2}{|l|}{ Concrete tensile strength } & \multicolumn{5}{|c|}{$f_{t 28}=2.5 \mathrm{MPa}$} \\
\hline \multicolumn{2}{|l|}{ Heat capacity } & \multicolumn{5}{|c|}{$C=1000 \mathrm{~J} /\left(\mathrm{kg} \cdot{ }^{\circ} \mathrm{C}\right)$} \\
\hline \multicolumn{2}{|l|}{ Heat transfer coefficient } & \multicolumn{5}{|c|}{$\alpha=50 \mathrm{~W} /\left(\mathrm{m}^{2} \cdot{ }^{\circ} \mathrm{C}\right)$} \\
\hline \multirow{2}{*}{$\begin{array}{l}\text { Thermal conductivity with } \\
\text { temperature }[4]\end{array}$} & $T,{ }^{\circ} \mathrm{C}$ & -155.67 & -101.11 & -59.44 & -17.78 & -23.39 \\
\hline & $k, \mathrm{~W} /\left(\mathrm{m} \cdot{ }^{\circ} \mathrm{C}\right)$ & 5.04 & 4.32 & 3.74 & 3.31 & 2.88 \\
\hline
\end{tabular}

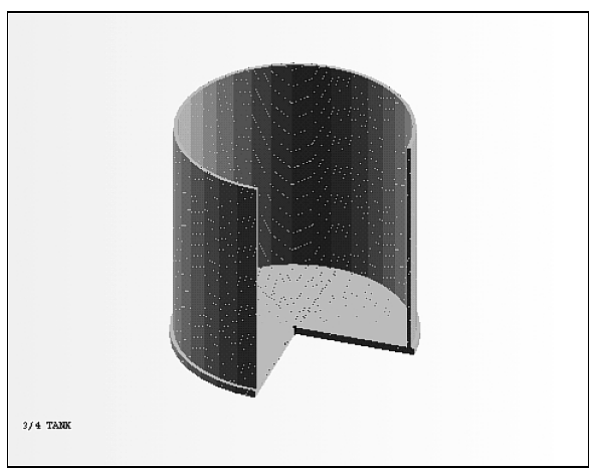

Fig. 1. Solid model (3D).

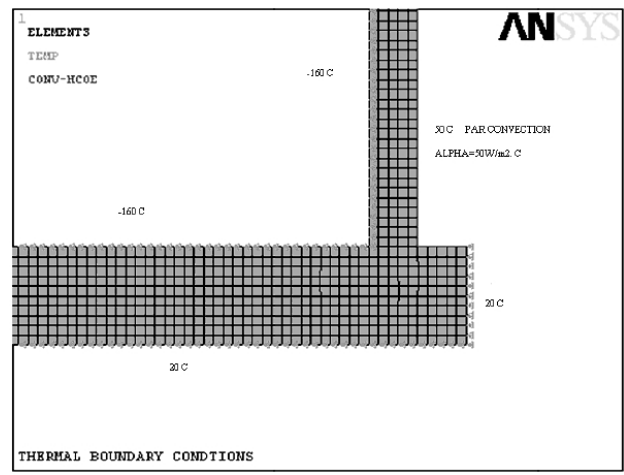

Fig. 2. Finite element model (2D axisymetric).

A thermal version of the model was used to calculate the temperature profile in the concrete tank; a structural version of the model then read the temperature profile to calculate stresses.

A two-dimensional four-nodal quadrilateral element having thermal degreeof-freedom (element type Plane 55 in ANSYS 8.0) is chosen for heat conduction problem.

The distributions of thermal elastic stress components were then calculated by switching the Plane 55 thermal element to Plane 42 structural element (Table 2) which is used for 2-D modeling of solid structures [5-7].

T a b 1 e 2

\section{Characteristics of Thermal and Structural Elements}

\begin{tabular}{|c|c|c||}
\hline Element & Thermal & Structural \\
\hline Type & Plane 55 & Plane 42 \\
\hline Number of nodes & 4 & 4 \\
\hline Number of DOF per node & 1 & 2 \\
\hline Nature & Temperature & Displacement $U_{X}$ and $U_{Y}$ \\
\hline
\end{tabular}

The geometry, node locations, and the coordinate system for these elements are shown in Figs. 3 and 4. 


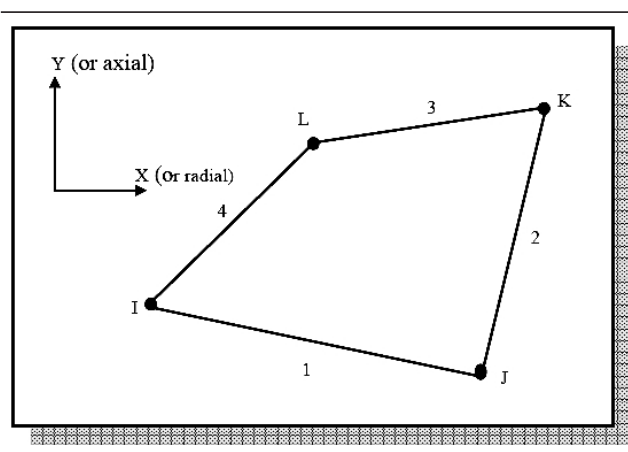

Fig. 3. Thermal 55 element.

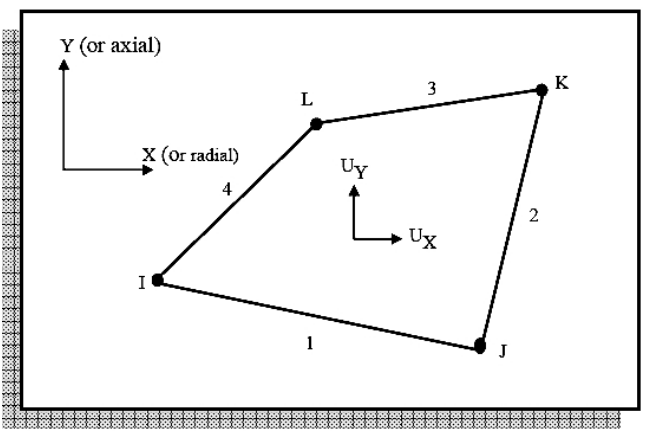

Fig. 4. Structural 42 element.

Transient Thermal Analysis. A transient thermal analysis determines the temperature distribution and other thermal quantities under conditions that vary over a period of time. Typical thermal quantities of interest are:

(i) the temperature distributions;

(ii) the amount of heat lost or gained;

(iii) thermal gradients;

(iv) thermal fluxes.

The mathematical solution for the axisymetrical element conduction heat transfer is based on the first law of thermodynamics - energy conservation law [1, $2,8,9]$

$$
\frac{1}{r} \frac{\partial}{\partial r}\left(k(T) r \frac{\partial T}{\partial r}\right)+\frac{\partial}{\partial z}\left(k(T) \frac{\partial T}{\partial z}\right)=\rho c \frac{\partial T}{\partial t},
$$

where $\rho$ is the density of material, $c$ is the heat capacity, and $k$ is the thermal conductivities of the concrete tank varying with temperature $T$.

Based on differential equation (1) with tacking into account of the spatial temporal boundaries conditions, the heat balance for the structural nodes at time $(t+\Delta t)$ is given by

$$
[C]\{\dot{T}\}+[K]\{T\}=\{F\}
$$

where $[C]$ is heat capacity matrix $c,[K]$ is conductance matrix containing the thermal conductivity terms $(k)$ and heat exchange coefficients $(\alpha),\{\dot{T}\}$ is nodal temperature rate vector $\partial T / \partial t$, and $\{F\}$ is thermal load vector (temperature, etc.).

A transient thermal analysis follows basically the same procedures as a steady-state thermal analysis. The main difference is that most applied loads in a transient analysis are functions of time. To specify time-dependent loads, one can divide the load-vs-time curve into load steps.

Thermal Boundary Conditions. A temperature of $-160^{\circ} \mathrm{C}$ was applied to the inside wall and base of the concrete tank, and $50^{\circ} \mathrm{C}$ was applied to the outside wall by convection with a film coefficient of $50 \mathrm{~W} /\left(\mathrm{m}^{2} \cdot{ }^{\circ} \mathrm{C}\right)$. The concrete initial temperature is set to $20^{\circ} \mathrm{C}$.

The temperature is obtained via the Galerkin finite element technique as implemented by ANSYS software package [5]. 
The Time Integration Parameter. The time integration parameter $\theta$ relates temperature difference to temperature rate:

$$
T_{n+1}-T_{n}=\Delta t_{n}(1-\theta) \dot{T}_{n}+\Delta t_{n} \theta \dot{T}_{n-1}
$$

Any value within $1 / 2 \leq \theta \leq 1$ is unconditionally stable. That is, all solutions are stable regardless of how large a time step $\Delta t_{n}$ is chosen. In ANSYS the default setting is $\theta=1 / 2$, known as the Crank-Nickolson technique. It is usable in the majority of transient problems. For thermal shock problems with nonlinearities, a higher value of $\theta$ is recommended to avoid oscillations in time of the solution. For the case of a brittle material like concrete, the Galerkin method was chosen with a $\theta=2 / 3$. Finally the reverse Euler integration scheme with $\theta=1$ would avoid oscillations but requires finer time steps to achieve comparable accuracy. Details about the algorithm are found in references [1, 10].

Thermal Results. The boundary conditions are implemented and the problem is solved using Frontal solver in ANSYS 8.0. The temperature distribution results are obtained in the general postprocessor. The results so obtained are plotted in Figs. 5, 6, and 7 for the temperature profiles and in Fig. 8 for the thermal flux vector. Figures 9, 10, 11, and 12 shows the temperature evolutions and profiles across the wall thickness and the base of the tank respectively. The temperature variations are nonlinear. This phenomenon can be attributed to the temperature dependence of the thermal conductivity of the concrete.

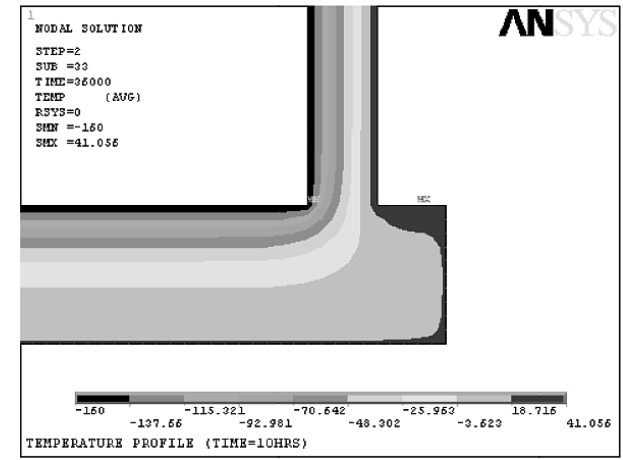

Fig. 5. Temperature profile at time $t=10 \mathrm{~h}$.

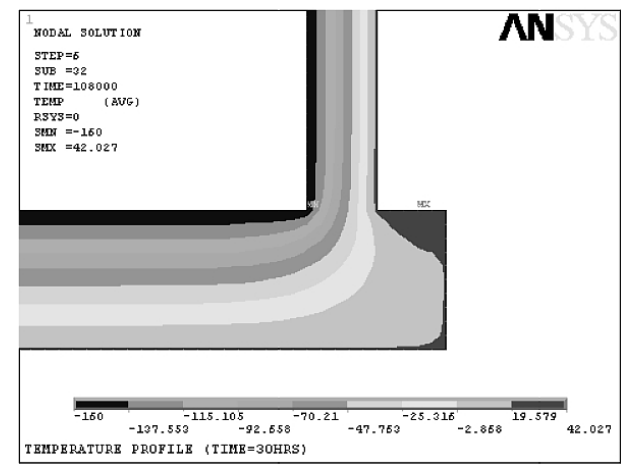

Fig. 7. Temperature profile at time $t=30 \mathrm{~h}$.

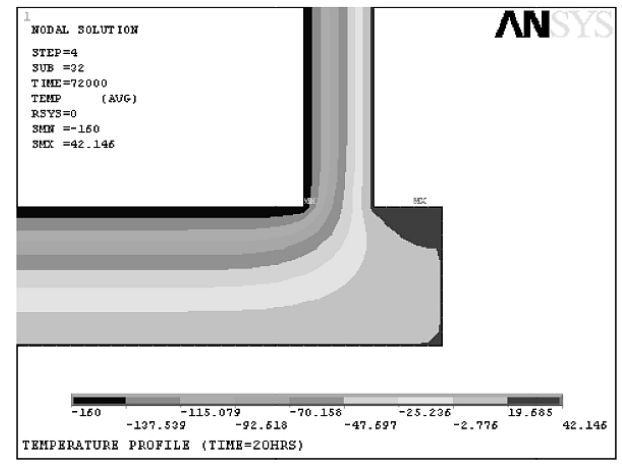

Fig. 6. Temperature profile at time $t=20 \mathrm{~h}$.

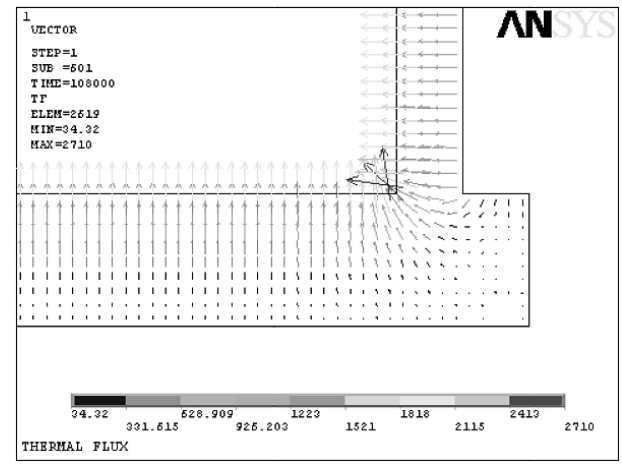

Fig. 8. Thermal flux vector at time $t=30 \mathrm{~h}$.

ISSN 0556-171X. Проблемы прочности, 2011, № 5 


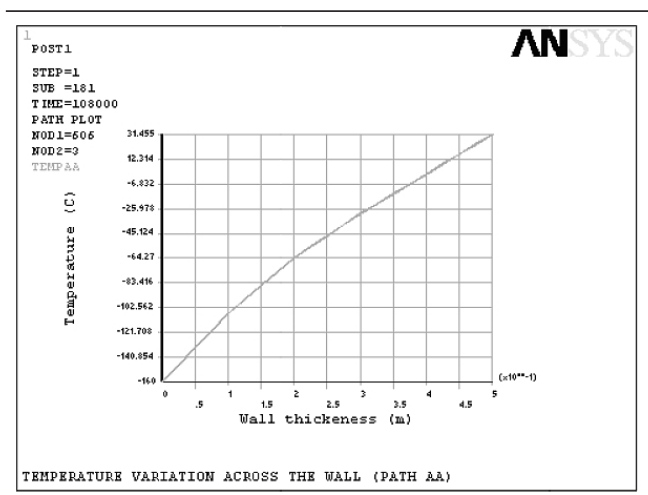

Fig. 9. Temperature variation across the wall.

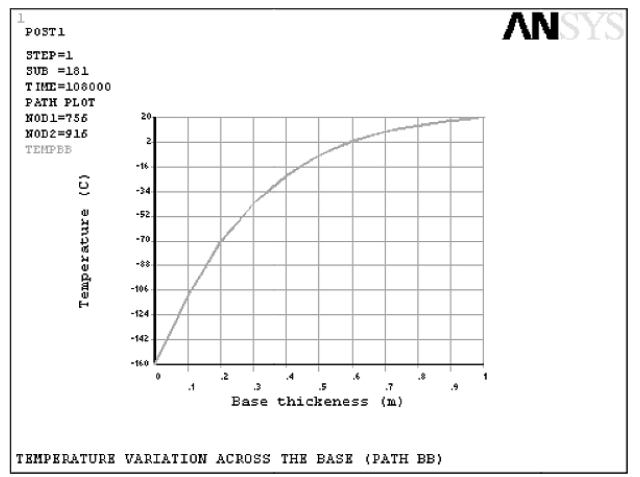

Fig. 11. Temperature variation across the base.

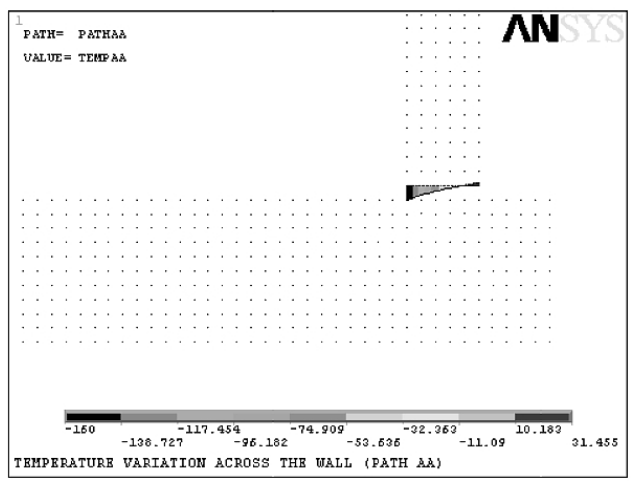

Fig. 10. Temperature profile across the wall.

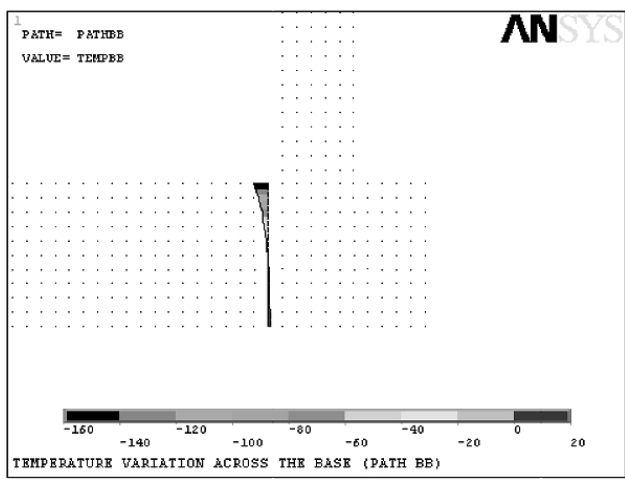

Fig. 12. Temperature profile across the base.

Structural Analysis. Thermal-stress applications are treated within framework of a so-called coupled-field analysis, which takes into account the interaction between thermal expansion/contraction and mechanical stress. Since in the present case strain does not influence on temperature, we are in a one way coupling situation best handled by the indirect method, where nodal temperatures from a (time transient) thermal analysis are applied at a specified time in the subsequent (steady state) stress analysis. The direct method involving one (time transient) thermomechanical analysis with a dedicated coupled field element may look attractive, but is not practicable for larger models because of the huge amount of cpu time and storage space required [10].

The change from thermal to structural analysis is easily achieved in ANSYS as the element switch is automatic. Thermal 55 elements to structural 42 element type.

The temperatures obtained from the previous analysis are now applied as a load to determine thermal stresses and displacements.

Element of Plane 42 type can be used either as a plane element (plane stress or plane strain) or as an axisymmetric element for a two dimensional modeling of solid structures $[5,7]$. The element is defined by four nodes having two degrees of freedom at each node: translations in the nodal $X$ and $Y$ directions. The geometry, node locations, and the coordinate system for this element are shown in Fig. 4. 


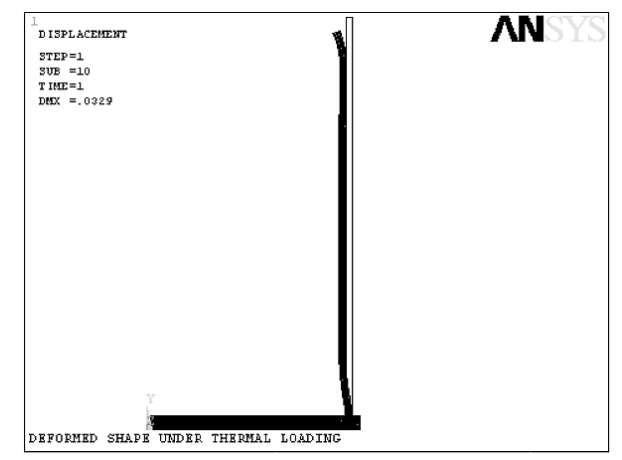

Fig. 13. Deformed shape (2D).

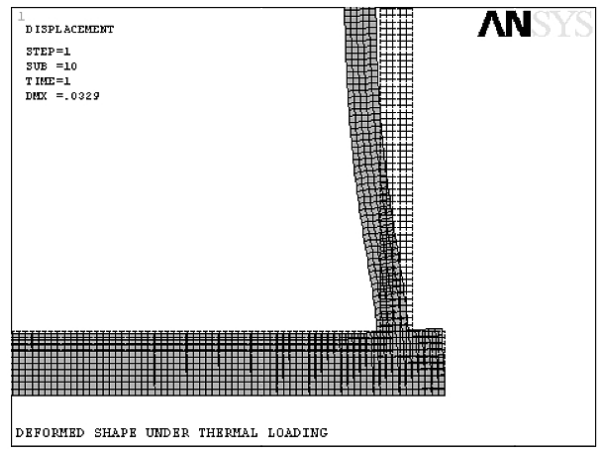

Fig. 15. Deformed shape at the wall-base junction.

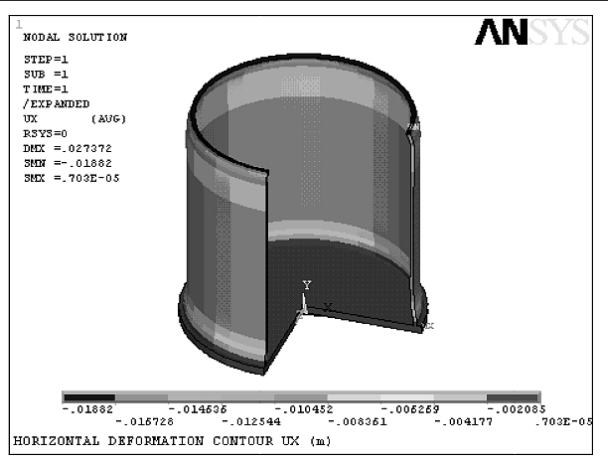

Fig. 14. Deformed shape (3D).

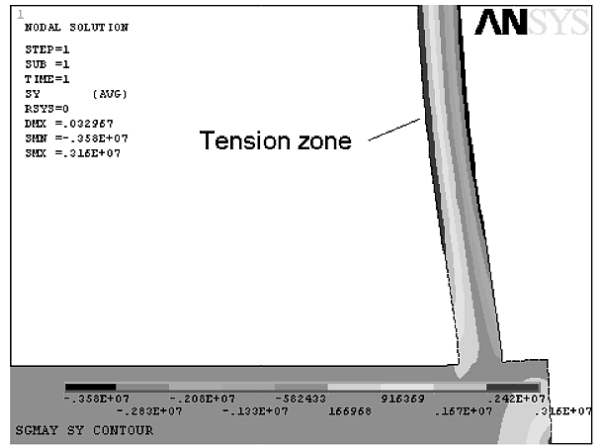

Fig. 16. $\sigma_{Y}$ stress profile.

Results and Discussion. According to the obtained results, the liquid of LNG produced:

- a great thermal gradient between the interior and the exterior of the tank (Figs. 6-11);

- a great thermal flux at the base-wall junction according to Fig. 8;

- a high values of tensile stresses (Fig. 16) which could worsen the static behavior of the tank during the service by causing the cracking of the concrete and enhancing the penetration of the liquid in the pores;

- a maximum shear forces at locations where thermal deformation is highly restrained, such as the intersection between wall and base slab.

The risk could be prevented with the adoption of suitable measurements:

- the insertion of the reinforcements in the tension zones to strengthen the concrete, thus reducing the formation of the cracks;

- providing prestress to control cracks;

- the use of a high performance concrete to increase resistance and to decrease the permeability [4];

- the use of a good insulation material like lightweight insulating concrete with a perlite aggregate (perlite concrete);

- introduce a special layer of steel ( $9 \%$ of nickel) interposed between the liquid and the internal walls of the tank to decrease the thermal shock;

- using lightweight aggregate concrete can benefit the prevention of thermal cracking. The lightweight aggregate concrete has larger strain at cracking, and thus, can sustain more thermal deformation before cracking [4]. 
Conclusions. This work deals with the peculiar aspects of the numerical modeling of thermal induced stresses in the reinforced LNG concrete tank.

The ANSYS finite element code has been employed for performing a sequential nonlinear transient thermal-structural analysis, taking into account the thermal dependant properties of the concrete as thermal conductivity. As shown from the results obtained. The LNG liquid generates a high temperature gradient between the interior and the exterior of the wall tank; this induces the appearance of high values of tensile stress that could worsen the static behaviour of the concrete tank in a "full" condition due to liquid penetration and following pore pressure rise and cracking of the concrete.

Moreover, these results provide the basis for further studies to get more insight into the degree of damage and the safety aspects connected with thermally induced stresses in the reinforced LNG concrete tank.

\section{Рез ом е}

Досліджуються залізобетонні резервуари для зберігання скрапленого природного газу, що мають ряд переваг порівняно зі стальними (висока кріогенна міцність, опір термошоку, втомі і втраті стійкості, вогнетривкість та ін.). Оскільки основним недоліком залізобетонних резервуарів $\epsilon$ низька міцність при розтязі, для оцінки рівня термічних розтяжних напружень розроблено числову модель, яка описує їх термомеханічний стан за кріогенних температур з урахуванням температурних залежностей теплофізичних властивостей бетону, в тому числі теплопровідності та питомої теплоємності.

1. ANSYS Heat Transfer, User Guide for Rev. 5.0, DN-S221:50, 6 (1993).

2. ANSYS Thermal Analysis, Tutorial for Rev. 5.0, DN-T031:50, 6 (1992).

3. V. Adams and A. Askenazi, Building Better Products with Finite Element Analysis, 1st edition, OnWord Press (1998), Chp. 14, pp. 411-423.

4. L. Dahmani, A. Khennan, K. Salah, "Behavior of the reinforced concrete at cryogenic temperature," Cryogenics, 47, 517-525 (2007).

5. ANSYS 8.0. The General-Purpose Finite Element Software. Documentation (2003).

6. E. Madenci and I. Guven, The Finite Element Method and Applications in Engineering Using ANSYS, Springer, New York (2006).

7. S. Moaveni, Finite Element Analysis: Theory and Application with ANSYS, Pearson Education Inc., New Jersey (2003).

8. F. Kreith and M. S. Bohn, Principles of Heat Transfer, Harper \& Row, New York (1986).

9. John H. Lienhard IV and John H. Lienhard V, A Heat Transfer Textbook, Third Edition, Phlogiston Press, Cambridge, Massachusetts (2008).

10. R. Chavan, A Thermomechanical Analysis of the Central Column Tiles, CRPP/EPFL - Lausanne, Internal Report INT 195/99 (1998-1999). 